\title{
Strategi Pengajaran Sains dengan Analogi Suatu Metode Alternatif Pengajaran Sains Sekolah
}

\section{Tjipto Prastowo}

Jurusan Fisika, FMIPA Unesa

email: t_prastowo@yahoo.com

\begin{abstract}
Abstrak
Peran analogi sebagai salah satu strategi pengajaran sains dalam menunjang proses belajar mengajar di sekolah sangat besar. Strategi ini dapat digunakan sebagai suatu metode alternatif untuk memecahkan kebuntuan komunikasi belajar antara guru dan siswa, khususnya bila siswa menghadapi kesulitan belajar dalam hal memahami materi ajar baru namun memiliki kemiripan alur berpikir dengan materi ajar sebelumnya. Sebagai basis berpikir metode pengajaran dengan analogi, artikel ini akan memperkenalkan dan mendiskusikan dua konsep utama, yaitu: konsep rujukan, materi ajar yang sudah dipahami sebelumnya oleh siswa, dan konsep target, materi ajar yang akan dipahamkan kepada siswa. Pembahasan kedua konsep tersebut akan disertai dengan beberapa contoh kasus dalam pengajaran fisika di sekolah. Tidak tertutup kemungkinan bagi para guru di kelas untuk memanfaatkan metode alternatif ini sebagai salah satu cara untuk meningkatkan keterampilan berpikir siswa. Dengan demikian, pengayaan materi ajar tidak saja dapat dilakukan melalui latihan soal berulang dan berjenjang, melainkan juga dapat dengan memperkenalkan paradigma baru agar diperoleh spektrum pemahaman materi ajar yang lebih luas dan komprehensif.
\end{abstract}




\section{Pendahuluan}

Seringkali seseorang memerlukan analogi atau padanan untuk menjelaskan suatu peristiwa tertentu kepada orang lain. Sebagai contoh, seorang guru sains memanfaatkan analogi untuk menjelaskan konsep-konsep yang dirasakan sulit oleh siswa, agar terbentuk pemahaman yang lebih baik tentang materi ajar tertentu. Dalam hal ini, kehadiran analogi mutlak diperlukan, khususnya jika materi ajar berhubungan dengan wilayah di luar jangkauan panca indera manusia atau alat bantu visual untuk pengamatan. Dalam skala atomik misalnya, dinamika elektron mengitari inti masif sebagai pusat atom dapat dianalogikan (pada batas tertentu) dengan peredaran planet-planet mengelilingi matahari sebagai pusat tata surya dalam jagad makrokosmos. Analogi juga digunakan oleh beberapa fisikawan tempo dulu dalam upaya untuk menjelaskan fenomena alam yang sulit dimengerti atau sebagai proses pembelajaran sains (Duit, 1991; Gribbin, 1998; Longair, 2003, Kurniasih dkk, 2009).

Contoh terkenal dalam hal ini adalah analogi antara gaya gravitasi (interaksi Newton) dan gaya elektrostatik (interaksi Coulomb), meskipun analogi keduanya berlaku sebagian saja (Glynn, 1995; Khairurrijal dkk, 2010).

Peran penting analogi sebagai metode alternatif pengajaran untuk mencari terobosan baru dalam proses pembelajaran sains mensyaratkan adanya kemiripan alur berpikir antara materi ajar yang sudah dimengerti sebelumnya oleh siswa dan materi ajar baru yang sedang dipelajari (Duit, 1991; Glynn, 1995). Kurniasih dkk (2009) menegaskan bahwa kemiripan alur berpikir dalam pelajaran fisika mencakup kronologi penalaran dan perangkat matematik yang digunakan untuk mendeskripsikan fenomena fisis yang sedang dipelajari. Agar analogi berjalan dengan efektif, maka diperlukan konsep rujukan, yaitu konsep fisika yang sudah diajarkan dan dipahami dengan baik oleh siswa. Konsep rujukan tersebut kemudian dikembangkan untuk menjelaskan konsep target, yaitu konsep fisika materi ajar baru. Perbandingan yang menyeluruh antara kedua konsep tersebut dapat memperluas cakrawala berpikir baik guru maupun siswa, dan mencegah terjadinya miskonsepsi dengan jalan mempertahankan prakonsepsi yang benar atau mengubah peta konsep berpikir siswa dari prakonsepsi yang salah menuju konsep yang benar sesuai teori yang berlaku untuk satu materi ajar tertentu (Brown, 1992; Clement, 1993). Bagi para guru sains, metode ini dapat digunakan untuk mengembangkan kreasi dan inovasi pembelajaran sains dalam arti sesungguhnya (Abdullah, 2009). Selain itu, metode ini bermanfaat untuk melatihkan keterampilan berpikir siswa dan menumbuh-kembangkan sikap-sikap positif seperti misalnya berpikir kritis, logis, dan analitis sebagai bagian dari pendidikan karakter (Sutrisno, 2009).

Tiga studi kasus sebagai contoh materi ajar yang mengeksploitasi peran analogi yang akan dibahas dalam artikel ini adalah: (1) analogi antara medan gravitasi dan medan elektrostatik beserta segala konsekuensinya; (2) analogi antara hukum II Newton tentang gerak dan hukum Ohm tentang arus listrik; dan (3) analogi antara aliran fluida dan aliran listrik. Sistematika penulisan artikel ini adalah sebagai berikut: metodologi strategi pengajaran dengan analogi dipaparkan pada bagian §2, pembahasan tiga kasus diuraikan pada bagian $\S 3$, diikuti dengan penutup pada bagian $\S 4$.

\section{Metodologi}

Metode pengajaran dengan analogi yang diangkat sebagai topik sentral dalam artikel ini adalah berdasarkan model Teaching With Analogies (TWA) yang dikembangkan oleh Glynn (1995). Model TWA membuat peta perbandingan 
(mapping) antara konsep rujukan dan konsep target. Bila terdapat banyak kemiripan antara kedua konsep tersebut, maka sebuah analogi berpikir dapat dibangun. Pada umumnya, model TWA terdiri dari beberapa tahap pelaksanaan, yaitu: (1) mengulas kembali konsep rujukan dan memperkenalkan konsep target pada saat bersamaan; (2) mengidentifikasi dan memetakan beberapa kemiripan atribut pada kedua konsep; (3) menceritakan batasan analogi antara kedua konsep; dan (4) menarik kesimpulan. Perlu diketahui bahwa materi ajar yang dijadikan sebagai bahan rujukan diasumsikan telah diajarkan terlebih dahulu sebelum materi ajar yang dijadikan sebagai target analogi. Namun demikian, situasi sebaliknya bisa saja terjadi, dimana materi ajar target datang mendahului materi ajar rujukan. Untuk mengatasi hal ini, maka konsep rujukan tetap harus disampaikan terlebih dahulu (dengan menghindari kompleksitas masalah berupa kerumitan matematik) kepada siswa sebelum pembahasan tentang konsep target dilakukan.

\section{Pembahasan}

\subsection{Medan Gravitasi dan Medan Elektrostatika}

Medan dalam pengertian yang lebih luas didefinisikan sebagai besaran fisis yang memiliki nilai di setiap titik dalam ruang. Terdapat dua jenis medan yang dikenal dalam bidang fisika, yaitu medan skalar dan medan vektor. Contoh medan skalar adalah distribusi temperatur dan tekanan udara dalam ruang terbuka, sedangkan contoh medan vektor adalah medan gravitasi, medan elektrostatika, medan magnetostatika, dan medan kecepatan fluida. Bagian ini hanya mengulas medan vektor saja dengan fokus pembahasan adalah sifat simetri (analogi) antara medan gravitasi dan medan elektrostatika. Dalam hal ini, perilaku medan vektor dapat dicari melalui operasi divergensi dan operasi curl, dimana operator nabla dimanfaatkan secara optimal. Melalui kedua macam operasi tersebut, diperoleh beberapa kemiripan sifat antara medan gravitasi dan medan elektrostatika (lihat Tabel 1) sebagai berikut: (1) massa benda adalah sumber medan gravitasi dan muatan listrik adalah sumber medan elektrostatika; perumusan matematis kedua medan adalah sama, dimana kekuatan medan pada suatu titik dalam ruang adalah berbanding lurus dengan kekuatan sumber dan berbanding terbalik dengan kuadrat jarak titik yang dimaksud dari sumber medan; (3) kehadiran medan gravitasi atau medan elektrostatika mutlak diperlukan agar terjadi gaya (interaksi) gravitasi Newton atau gaya (interaksi) Coulomb; (4) medan gravitasi dan medan elektrostatika merupakan medan konservatif, dengan demikian menghasilkan gaya konservatif yang menjamin eksistensi kekekalan energi.

Meskipun banyak kemiripan sifat, namun terdapat perbedaan antara medan gravitasi dan medan listrik. Gaya (interaksi) gravitasi selalu bersifat tarik menarik, sedangkan interaksi Coulomb bisa bersifat tarik menarik atau tolak menolak bergantung pada jenis muatan listrik yang berinteraksi. Namun demikian, perbedaan tersebut tidak mengurangi esensi analogi kedua medan. Bagaimanapun, bila dikehendaki kemiripan sifat yang sempurna, maka menarik membayangkan sifat anti gravitasi dari suatu materi bermassa negatif (sebagai konsekuensi dari sifat anti gravitasi yang bersifat spekulatif). 
Tabel 1. Perbandingan antara medan gravitasi dan medan elektrostatika

\begin{tabular}{|c|c|c|}
\hline $\begin{array}{c}\text { Sifat yang } \\
\text { dibandingkan }\end{array}$ & $\begin{array}{c}\text { Medan } \\
\text { Gravitasi }\end{array}$ & $\begin{array}{c}\text { Medan } \\
\text { Elektrostatik } \\
\text { a }\end{array}$ \\
\hline sumber & $\mathrm{m}$ & $\mathrm{q}$ \\
\hline kekuatan & $\sim \mathrm{r}^{-2}$ & $\sim \mathrm{r}^{-2}$ \\
\hline $\begin{array}{c}\text { sifat } \\
\text { konservatif }\end{array}$ & $\nabla \times \vec{g}=0$ & $\nabla \times \vec{E}=0$ \\
\hline interaksi & $\vec{F}_{g}=m \vec{g}$ & $\vec{F}_{e}=q \vec{E}$ \\
\hline
\end{tabular}

\subsection{Hukum II Newton dan Hukum Ohm}

Pada prinsipnya, hukum II Newton yang mengatur dinamika gerak benda dan penyebabnya menceritakan tentang interaksi antara sistem dan lingkungan. Sistem fisis berupa obyek yang sedang diamati, sedangkan lingkungan adalah gaya luar yang mempengaruhi keadaan dinamik dari sistem fisis tersebut. Selama tidak ada gaya luar yang bekerja, maka benda (sistem fisis) akan tetap berada dalam keadaan diam atau bergerak dengan kecepatan tetap. Perubahan keadaan dinamik dalam bentuk perubahan kecepatan merupakan respons dari gaya luar yang diberikan. Dalam hal ini, gaya luar berfungsi sebagai variabel manipulasi, sedangkan perubahan kecepatan per satuan waktu atau sering disebut dengan percepatan berfungsi sebagai variabel respons. Terdapat kesebandingan antara gaya luar yang diberikan pada benda dan percepatan yang dialami oleh benda. Hubungan kesebandingan tersebut berubah menjadi suatu persamaan jika suatu tetapan kesebandingan dilibatkan. Dalam hal ini, tetapan kesebandingan yang dimaksud adalah merupakan karakteristik dari benda tersebut yang memberikan "resistansi gerak" atau bersifat inersia (lembam) terhadap pengaruh dari luar, dan dikenal sebagai besaran massa.

Dengan alur berpikir yang sama, bila ujung-ujung kawat konduktor diberi tegangan luar (beda potensial listrik) yang berasal dari sumber arus (baterei), maka akan mengalir arus listrik pada konduktor tersebut. Secara mikroskopik, arus listrik merupakan aliran gerak elektron dalam arah yang berlawanan dengan arah arus. Jadi, arus yang mengalir merupakan respons dari tegangan luar yang diberikan. Dalam hal ini, tegangan luar berfungsi sebagai variabel manipulasi. Terdapat kesebandingan antara tegangan luar yang diberikan dan besar arus yang mengalir pada kawat konduktor. Hubungan kesebandingan tersebut berubah menjadi suatu persamaan jika suatu tetapan kesebandingan dilibatkan. Dalam hal ini, tetapan kesebandingan yang dimaksud merupakan karakteristik dari kawat konduktor tersebut yang memberikan "resistansi listrik" terhadap pengaruh luar, dan dikenal sebagai besaran hambatan. Perbandingan kemiripan sifat-sifat hukum II Newton dan hukum Ohm dapat dilihat pada Tabel 2 di bawah ini.

Tabel 2. Perbandingan antara hukum II Newton dan hukum Ohm

\begin{tabular}{|c|c|c|}
\hline $\begin{array}{c}\text { Sifat yang } \\
\text { dibandingkan }\end{array}$ & $\begin{array}{c}\text { Hukum II } \\
\text { Newton }\end{array}$ & $\begin{array}{c}\text { Hukum } \\
\text { Ohm }\end{array}$ \\
\hline $\begin{array}{c}\text { bentuk } \\
\text { matematis }\end{array}$ & $F \infty a$ & $V \infty I$ \\
$\begin{array}{c}\text { tetapan } \\
\text { kesebandingan }\end{array}$ & $\mathrm{m}$ & $\mathrm{R}$ \\
\hline sifat tetapan & $\begin{array}{c}\text { resistansi } \\
\text { gerak }\end{array}$ & $\begin{array}{c}\text { resistansi } \\
\text { listrik }\end{array}$ \\
\hline sifat persamaan & $\begin{array}{c}\text { bukti } \\
\text { kekekalan } \\
\text { energi }\end{array}$ & $\begin{array}{c}\text { kekti } \\
\text { kekalan } \\
\text { energi }\end{array}$ \\
\hline
\end{tabular}

\subsection{Aliran Fluida dan Aliran Arus Listrik}

Fluida (cair, gas, dan plasma) didefinisikan sebagai zat yang dapat mengalir. Dinamika fluida diatur melalui hukum Newton untuk medium kontinu yang sering dikenal sebagai persamaan Navier-Stokes. Bila aliran arus listrik 
dikendalikan oleh beda potensial sebagai driving force, maka fluida memerlukan kehadiran beda tekanan sebagai penyebab aliran. Secara alami, arus listrik dan fluida akan mengalir dari potensial listrik/gravitasi tinggi ke potensial listrik/gravitasi rendah. Hal sebaliknya bisa saja terjadi, namun memerlukan kerja luar yang ditambahkan. pada sistem. Sebagai contoh, air tanah bisa sampai ke permukaan karena telah digunakan pompa baik mekanik maupun listrik. Dalam hal ini, baik secara alami maupun dengan bantuan alat untuk memberikan sejumlah energi tambahan, aliran fluida dan aliran arus listrik selalu menjamin kekekalan energi sepanjang tidak terdapat energi yang hilang dalam bentuk panas. Perbandingan kemiripan sifat aliran fluida dan aliran arus listrik dapat dilihat pada Tabel 3 berikut ini.

Tabel 3. Perbandingan antara aliran fluida dan aliran arus listrik

\begin{tabular}{|c|c|c|}
\hline $\begin{array}{l}\text { Sifat yang } \\
\text { dibandingkan }\end{array}$ & $\begin{array}{c}\text { Aliran } \\
\text { Fluida }\end{array}$ & $\begin{array}{c}\text { Aliran } \\
\text { Listrik }\end{array}$ \\
\hline penyebab & $\begin{array}{c}\text { beda } \\
\text { tekanan }\end{array}$ & $\begin{array}{c}\text { beda } \\
\text { potensial }\end{array}$ \\
\hline sifat aliran & $\begin{array}{c}\text { dari } \\
\text { potensial } \\
\text { tinggi } \\
\text { ke } \\
\text { potensial } \\
\text { rendah }\end{array}$ & $\begin{array}{c}\text { dari } \\
\text { potensial } \\
\text { tinggi } \\
\text { ke } \\
\text { potensial } \\
\text { rendah }\end{array}$ \\
\hline sifat & $\begin{array}{c}\text { bukti } \\
\text { kekekalan } \\
\text { energi }\end{array}$ & $\begin{array}{c}\text { bukti } \\
\text { kekekalan } \\
\text { energi }\end{array}$ \\
\hline
\end{tabular}

\section{PENUTUP}

Analogi memainkan peran vital dalam proses pembelajaran sains sekolah melalui pengajaran yang kreatif dan inovatif oleh guru sains, serta pelatihan keterampilan berpikir dan pembentukan kepribadian siswa melalui tindak kritis, logis, dan analitis. Walaupun strategi pengajaran sains dengan analogi diyakini dapat mempermudah proses belajar siswa, namun penerapan teknik ini di kelas harus memperhatikan beberapa hal, misalnya prakonsepsi dan daya serap siswa, untuk menghindari terjadinya miskonsepsi. Sampai dengan saat ini, sejauh pengetahuan penulis belum ada bukti empiris atau kajian kuantitatif melalui penelitian pendidikan dengan topik "Using TWA in Learning Science" yang dilakukan oleh sivitas akademik di Unesa. Oleh karena itu, sebagai suatu gagasan alternatif dalam pembelajaran sains meski bukan hal baru di tingkat internasional, metode alternatif ini layak dicoba untuk dilatihkan kepada mahasiswa baik program sarjana maupun program pascasarjana Unesa, agar penelitian pendidikan di lingkungan FMIPA dan Program Magister Pendidikan Sains Unesa memiliki topik yang tidak monotonik. Pada akhirnya, uji kelayakan metode pengajaran dengan analogi melalui penelitian kelas dengan melibatkan siswa sekolah atau mahasiswa program sarjana sangat diperlukan untuk mengetahui korelasi antara metode ini dan hasil belajar siswa sekolah atau mahasiswa FMIPA Unesa.

\section{Daftar Pustaka}

1. Abdullah, M. 2009. Kreatif dan Inovatif dalam Pengajaran Sains. Jurnal Pengajaran Fisika Sekolah Menengah, Vol.1, No.2, 27-28.

2. Brown, D. E. 1992. Using Examples and Analogies to Remediate Misconceptions in Physics: Factors influencing conceptual change. Journal of Research in Science Teaching, Vol.29, No.1, 17-34.

3. Clement, J. 1993. Using Bridging Analogies and Anchoring Intuitions to Deal with Students' Preconceptions in Physics. Journal of Research in Science Teaching, Vol.30, No.10, 1241-1257. 
4. Duit, R. 1991. On the Role of Analogies and Metaphors in Learning Science. Science Education, Vol.75, 649-672.

5. Glynn, S. M. 1995. Conceptual Bridges: Using analogies to explain scientific concepts. The Science Teacher, Vol.62 (9), 25-27.

6. Gribbin, J. 1998. A Brief History of Science. The Ivy Press Ltd. Sussex, UK.

7. Khairurrijal, N. Kurniasih, E. J. Mustopa, dan M. Abdullah. 2010. Konsep Medan Listrik Menggunakan Analogi Konsep Medan Gravitasi untuk Pengajaran Fisika di Sekolah Menengah Atas. Jurnal Pengajaran Fisika

Sekolah Menengah, Vol.1, No.78, 8285.

8. Kurniasih, N., Novitrian, W. Srigutomo. 2009. Pengajaran Konduksi Termal Menggunakan Analogi Konduksi Listrik. Jurnal Pengajaran Fisika Sekolah Menengah, Vol.1, No.3, 82-85.

9. Longair, M. 2003. Theoretical Concepts in Physics. Cambridge Uni Press. Cambridge, UK.

10. Sutrisno, W. 2009. Penumbuhan Sikapsikap Positif Melalui Pembelajaran Fisika. Jurnal Pengajaran Fisika Sekolah Menengah, Vol.1, No.1, 14-17. 